\title{
DZIECI I MŁODZIEŻ SZKOLNA WOBEC AGRESJI I PRZEMOCY SŁOWNEJ W INTERNECIE
}

\section{Abstract \\ THREATS TO SCHOOL CHILDREN BY HATE SPEECH ON THE INTERNET}

The internet is a natural environment for school children. Some of the messages through it are aggression and verbal violence. The aim of the article is to show the phenomenon of aggression and verbal violence on the Internet towards school children and adolescents. The subject of the research contained in the article are school children and adolescents as recipients and victims of hate speech on the Internet. Research problems are questions about the level of online threats to schoolchildren, how the Polish education system prevents this and how it protects children from these threats. In search of answers to these questions, the author used published research data, showing the activity of children on the Internet, He also reviewed the basics of teaching in terms of preparing students to avoid hate speech on the internet.

The basic research methods are document examination and method of analysis and logical construction. The research shows two key conclusions as answers to research problems. First of all, the level of threat to school children and youth by aggression and verbal violence is significant, because every third teenager was a victim of violence or verbal aggression on the Internet. Secondly, the Polish education system did not protect students from these threats. Schools did not teach children proper behavior on the internet.

Key words: hate speech, schoolchildren, education, threats, social media, aggression, verbal violence, internet

\section{Wprowadzenie}

Aktywność dzieci i młodzieży szkolnej w Internecie oraz związanych z nim mediach społecznościowych jest już powszechna, choć zróżnicowana pod względem rozmaitych czynników, w tym szczególnie wieku. Dla uczniów środowisko cyfrowe ma często znaczenie pierwszoplanowe ze wszystkimi konsekwencjami tego 
stanu. Jednym z nich jest oddziaływanie przekazów o charakterze agresji i przemocy słownej. Choć przekazy te mają bogatą tradycję i formy znacznie wykraczające poza historię i obecne funkcjonowanie Internetu, to z powodu jego wzrastającej siły oddziaływania na najmłodszych użytkowników stają się ważnym wyzwaniem edukacyjnym. Szkoły powinny przygotowywać uczniów do właściwego korzystania $\mathrm{z}$ Internetu, $\mathrm{w}$ tym także odpowiednich zachowań wobec zagrożeń mową nienawiści. Pomimo że wieloraka aktywność dzieci i młodzieży w Internecie odbywa się głównie poza samą szkołą, to kluczowe znaczenie dla kształtowania odpowiednich zachowań związanych z tą aktywnością przypada edukacji szkolnej. Jej częścią jest edukacja medialna, która coraz bardziej ma przenosić uwagę z technicznych umiejętności cyfrowych na efektywne i bezpieczne korzystanie ze wszystkich mediów cyfrowych. Rację ma Grzegorz Ptaszek, postulując, by edukacja ta jak najszerzej dostosowywała się do zmieniających się doświadczeń młodych ludzi w ich kontaktach $\mathrm{z}$ mediami cyfrowymi i nowymi technologiami komunikacyjnymi ${ }^{1}$. Celem artykułu jest ukazanie zjawiska agresji oraz przemocy słownej w Internecie wobec dzieci i młodzieży, a także założeń programowych obowiązujących polskie szkoły, pod kątem zapobiegania i przeciwdziałania internetowej mowie nienawiści.

\section{Metodologia}

Przedmiotem badań zawartych w artykule są dzieci i młodzież szkolna jako adresaci i ofiary internetowej agresji i przemocy słownej. Problemy badawcze stanowią pytania o to, jaki jest poziom zagrożeń dzieci i młodzieży szkolnej przez internetowe formy agresji i przemocy słownej, jak polski system edukacyjny sobie z tym radzi, czy i w jakim zakresie podąża za nowymi wyzwaniami, a w szczególności: czy i jak chroni dzieci oraz młodzież przed tymi zagrożeniami. W poszukiwaniu odpowiedzi na te pytania autor sięgnął do publikowanych danych $z$ badań, głównie sondażowych, ukazujących aktywność dzieci i młodzieży w Internecie ${ }^{2}$, oraz dokonał przeglądu podstaw programowych pod kątem zawartości w nich treści związanych z przygotowywaniem uczniów do unikania przekazów agresji i przemocy słownej ${ }^{3}$. Podstawowe metody badawcze zastosowane przez autora to badanie dokumentów oraz metoda analizy i konstrukcji logicznej.

1 G. Ptaszek, Edukacja medialna 3.0. Krytyczne rozumienie mediów cyfrowych $w$ dobie Big Data i algorytmizacji, Wydawnictwo Uniwersytetu Jagiellońskiego, Kraków 2019, s. 161-165.

2 Są to przede wszystkim ogólnopolskie badania młodzieży „Nastolatki wobec Internetu 3.0” z roku 2016, zrealizowane przez Pracownię Edukacyjnych Zastosowań Technologii Informacyjno-Komunikacyjnych NASK, oraz Polskie Badanie EU Kids Online 2018 Uniwersytetu im. Adama Mickiewicza w Poznaniu.

3 Najważniejsze $\mathrm{z}$ nich to podstawy programowe wychowania przedszkolnego oraz kształcenia ogólnego w poszczególnych typach szkół, wydawane w trybie rozporządzeń Ministra Edukacji Narodowej. 


\section{Cyberagresja i cyberprzemoc}

Termin „agresja” odnosi się do bardzo wielu różnorodnych działań mających wrogi bądź napastliwy charakter. To pojęcie przede wszystkim potoczne, wprowadzone do nauki głównie przez pedagogów, psychologów, a także socjologów. Jest używane $\mathrm{w}$ rozmaitych kontekstach sytuacyjnych i odnosi się do różnych aspektów ludzkiego postępowania. W zależności od dyscypliny badań i przyjętej metodologii ujmuje się ją jako cechę, stan czy proces, a wynikiem postępowania badawczego są różne definicje zachowań agresywnych.

$\mathrm{Z}$ pojęciem agresji powiązane jest pojęcie przemocy, a oba te terminy są bliskoznaczne, trudno rozróżnialne w praktyce społecznej. W istocie jednak różnią się ważnym elementem. W zachowaniach agresywnych jest równowaga w sile psychicznej lub fizycznej pomiędzy osobami, oznaczająca, że mają one zbliżone możliwości zarówno jeżeli chodzi o atakowanie, jak i zdolności do skutecznej obrony. Natomiast przemoc związana jest $\mathrm{z}$ nierównowagą sil, gdy osoba posiadająca przewagę fizyczną lub psychiczną używa jej przeciw osobie słabszej. W przypadku przemocy stosowane są te same formy zachowań jak w przypadku agresji ${ }^{4}$.

Za twórcę klasycznej definicji agresji uważa się Arnolda H. Bussa, który pojmował ją jako „reakcję dostarczającą szkodliwych bodźców innemu organizmowi”. $\mathrm{W}$ pedagogice dominuje ujęcie agresji jako zachowania podejmowanego $\mathrm{z}$ zamiarem spowodowania szkody, prowadzącego potencjalnie lub faktycznie do negatywnych dla innych konsekwencji. Rozpatruje się też agresję jako wewnętrzny stan emocjonalno-motywacyjny jednostki, cechujący się irytacją, złością, gniewem, chęcią szkodzenia i niszczenia, czy w końcu jako skłonność do częstego używania przemocy w relacjach $\mathrm{z}$ innymi lub sposób rozwiązywania konfliktów, a także realizacji celów życiowych ${ }^{6}$.

W psychologii termin „agresja” oznacza działanie skierowane przeciwko osobom lub przedmiotom wywołującym u jednostki niezadowolenie lub gniew, a celem takiego działania jest wyrządzenie szkody przedmiotowi agresji, określonym osobom czy grupom społecznym. Philip Zimbardo definiuje agresję jako reakcję „polegającą na niszczeniu przedmiotów, wyrządzaniu krzywdy innym lub sobie samemu (lub wyraźnej intencji dokonania tego), która przyjmuje wiele różnych postaci”

Socjologowie z kolei akcentują powiązanie czynów agresywnych w miejscach zarówno publicznych, jak i prywatnych ze zmianami społecznymi, dynamicznym

4 J. Kołodziejczyk, Agresja i przemoc w szkole, NODN SOPHIA, Kraków 2004, s. 6.

5 A.H. Buss, The Psychology of Aggression, Wiley and Sons, New York 1961, s. 1, [w:] J. Cichla, Dynamika i uwarunkowania przemian psychospołecznego funkcjonowania kobiet - ofiar przemocy domowej - w trakcie procesu terapeutycznego, s. 11, http://www.sbc.org.pl/Content/98297/doktorat3462.pdf (dostęp: 3.08.2019).

6 Zob. B. Milerski, B. Śliwerski, Pedagogika, Wydawnictwo Naukowe PWN, Warszawa 2000, s. $8-9$.

P.G. Zimbardo, F.L. Ruch, Psychologia i życie, Wydawnictwo Naukowe PWN, Warszawa 1996, s. 661 . 
rozwojem technologicznym oraz informatycznym. Dla objaśnienia tego zjawiska przywołuje się najczęściej: teorię anomii Roberta K. Mertona, teorię zróżnicowanych powiązań Edwina H. Sutherlanda, teorię kontroli społecznej Travisa Hirschiego, teorię naznaczenia społecznego (stygmatyzacji) oraz teorię dryfu Davisa Matzy i Greshama Sykesa ${ }^{8}$.

Jednym z podstawowych narzędzi agresji i przemocy jest słowo. Wyrażane nim przekazy mogą przybierać formę bezpośrednich wypowiedzi napastliwych, szkodzących i poniżających, ale też pośrednich ich odmian, mających wyrządzić przykrość lub szkody danej osobie poprzez skierowanie wypowiedzi agresywnej do osób trzecich.

Słowne zachowania agresywne i przemocowe, choć są aspołeczne, istniały zawsze. Wraz jednak ze wzrostem wykorzystania cyfrowej technologii informacyjnej we wszystkich sferach życia dramatycznie przybrały na sile. Jednym z kluczowych obszarów występowania tego zjawiska jest Internet i związane z nim media społecznościowe. Agresję i przemoc stosowane z użyciem Internetu oraz innych narzędzi typu elektronicznego określa się jako cyberagresję i cyberprzemoc. Do najważniejszych ich odmian Magdalena Cyrklaff-Gorczyca zalicza:

- wojnę na obelgi (ang. flaming) - zwykle publiczną i agresywną (pełną wulgaryzmów) wymianę zdań między uczestnikami na przykład grup dyskusyjnych;

- prześladowanie, szykanowanie (ang. harrassment) - regularne przesyłanie agresywnych i/lub ośmieszających wiadomości do ofiary;

- oczernianie (ang. slandering) - wysyłanie przez sprawcę informacji mających na celu zniszczenie reputacji ofiary i jej dobrych relacji z innymi;

- kradzież tożsamości, podszywanie się (ang. impersonation);

- wysyłanie przez sprawcę z konta ofiary obraźliwych komentarzy i/lub informacji (zwykle o osobach publicznych);

- upublicznianie tajemnic (ang. outing) - udostępnianie przez sprawcę osobom trzecim prywatnych materiałów ofiary (może mu towarzyszyć szantażowanie);

- prowokowanie i/lub atakowanie osoby oraz dokumentowanie jej reakcji za pomocą filmu lub zdjęć (ang. happy slapping);

- poniżanie (ang. denigration) - upublicznianie poniżających, nieprawdziwych, informacji i/lub materiałów;

- śledzenie (ang. cyberstalking) - polegające na inwigilacji ofiary drogą elektroniczną i nękaniu jej niechcianymi komunikatami, szykanami, groźbami o charakterze prześladowczym9.

8 M. Przybysz-Zaremba, Egzemplifikacje wybranych teorii zachowań agresywnych człowieka perspektywa trójwymiarowa, „Studia nad Rodziną” 2015, R. XIX, nr 2 (37), s. 322.

9 M. Cyrklaff-Gorczyca, Cyberstalking jako forma przemocy $z$ wykorzystaniem technologii informacyjno-komunikacyjnych, [w:] K. Materska, B. Taraszkiewicz (red.), Ekologia informacji a zasoby informacyjne $w$ bibliotekach i cyberprzestrzeni, Biblioteka Uczelniana Akademii Pomorskiej, 


\section{Dzieci i młodzież jako użytkownicy Internetu}

Prawie wszystkich aktualnych uczniów zaliczyć można do kategorii digital natives, $\mathrm{w}$ takim znaczeniu, jakie podaje Marc Prensky ${ }^{10}$. Urodzeni w czasach powszechnego stosowania w życiu codziennym i zawodowym technologii komputerowych, traktują Internet jako zwyczajny element otaczającego ich świata.

Większość dzieci otrzymuje pierwszy smartfon w wieku około ośmiu lat - tak wynika z badania F-Secure i sieci Plus „Bezpieczny smartfon dla dziecka”. Wśród uczniów pierwszych klas szkół podstawowych już przeszło 80\% ma do swojej dyspozycji telefon, który łączy się z Internetem. Korzystają z niego średnio przez 2,5 godziny dziennie i jest to dla nich czymś zupełnie naturalnym, a wpisy na internetowym profilu często są ważniejsze niż reputacja wśród kolegów z podwórka. Ponad 25\% rodziców deklaruje, że ich dzieci w tak wczesnym wieku korzystają z Facebooka, kolejne $10 \%$ - że z innych mediów społecznościowych" ${ }^{11}$.

Pierwsze miejsce wśród urządzeń służących do łączenia się z Internetem zajmuje telefon komórkowy/smartfon (korzystało z niego już w 2017 roku codziennie lub częściej 82,5\% badanych). W dalszej kolejności są to: telewizor, a następnie laptop i komputer stacjonarny (kolejno $57 \%$ i $40 \%)^{12}$.

Wszyscy uczniowie używają Internetu (tylko 0,7\% nie czyni tego w ogóle). Większość korzysta $\mathrm{z}$ niego wiele razy dziennie lub cały czas. Najczęściej odbywa się to w domu i w szkole $(99,3 \%$ i $82,2 \%)$. Nawet w drodze do lub ze szkoły nie rezygnują z aktywności internetowej (przeszło 60\%) ${ }^{13}$.

Wraz z wiekiem rośnie intensywność relacji dzieci i młodzieży z mediami cyfrowymi. O ile $\mathrm{w}$ wieku 6-12 lat czas kontaktu $\mathrm{z}$ nimi wynosi średnio 11 godzin tygodniowo, o tyle dla dzieci w wieku 13-15 lat osiąga już 17 godzin w tygodniu, a w grupie wiekowej 16-19 lat - przeszło 21 godzin na tydzień ${ }^{14}$.

Jednym ze sposobów korzystania $z$ Internetu jest posiadanie własnego profilu w portalu społecznościowym. Przeszło 70\% (72,6\%) dzieci i młodzieży deklaruje posiadanie takiego profilu, $w$ tym prawie $50 \%$ dzieci w wieku 9-10 lat ${ }^{15}$.

Pedagogiczna Biblioteka Wojewódzka w Słupsku, Stowarzyszenie Bibliotekarzy Polskich - Zarząd Oddziału, Słupsk 2017, s. 203.

10 M. Prensky, Digital Natives, Digital Immigrants (dostęp: 20.03.2019).

11 K. Małagocka, M. Nowowiejski, 80 proc. dzieci w wieku 7-8 lat ma własny smartfon. Korzystają $z$ niego średnio 2,5 godziny dziennie, https://biznes.newseria.pl/news/80-proc-dzieciw-wieku,p1003907867 (dostęp: 15.03.2019).

12 Polskie badanie EU Kids Online 2018, Wydawnictwo Naukowe Uniwersytetu im. Adama Mickiewicza w Poznaniu, 2019, s. 20 (dostęp: 4.04.2019).

13 Raport z badania. Nastolatki 3.0, s. 7, https://akademia.nask.pl/publikacje/Raport_z_badania_Nastolatki_3_0.pdf (dostęp: 10.04.2019).

14 A. Piecuch, Cyfrowy świat dzieci i młodzieży, „Lubelski Rocznik Pedagogiczny” 2017, t. XXXVI, z. 4, s. 80.

15 Polskie badanie EU Kids Online 2018, s. 21. 
Najpopularniejsze serwisy społecznościowe wśród młodzieży to: Facebook, Snapchat i Instagram. Portale społecznościowe służą nastolatkom przede wszystkim do autoprezentacji, komunikowania się i poznawania innych osób oraz do dzielenia się różnymi materiałami (własnymi i zapożyczonymi). Na swoich profilach nastolatki najczęściej publikują własne zdjęcia i filmy, informacje oraz komentarze dotyczące bieżącego dnia, linki do filmów i zdjęć pochodzących z innych serwisów internetowych, memy, zdjęcia innych osób, a także linki do artykułów $\mathrm{z}$ innych serwisów.

\section{Agresja i przemoc słowna w Internecie jako zagrożenie dla dzieci i młodzieży szkolnej}

Powszechne korzystanie przez dzieci z Internetu i różnych portali społecznościowych stanowi naturalną niejako podstawę do sieciowych zagrożeń agresją oraz przemocą słowną. Treści słowne o charakterze nienawistnym najczęściej spotykane są na popularnych stronach www, a więc: portalach społecznościowych, forach internetowych, blogach, dyskusjach prowadzonych pod artykułami w serwisach informacyjnych.

Ważnych informacji o skali i strukturze tego zjawiska dostarczają wyniki badań „Nastolatki 3.0”. Według Anny Borkowskiej i Agnieszki Wrońskiej większość badanych nastolatków (w wieku 11-17 lat) ma styczność z różnego rodzaju szkodliwymi treściami w Internecie i tylko $28 \%$ z nich deklaruje, że się z nimi nie spotkało. Agresja i przemoc słowna w sieci, którą dzieci zauważają, to najczęściej: wyzwiska $(59,7 \%)$, poniżanie i ośmieszanie $(58,1 \%)$, podszywanie się $(40,5 \%)$, straszenie $(34,2 \%)$, rozpowszechnianie kompromitujących treści $(33,3 \%)$ oraz szantażowanie $(24,4 \%)$. Są także ofiarami agresji i przemocy elektronicznej, bowiem co trzeci z nastolatków był wyzywany w Internecie $(32,2 \%)$, prawie co piąty poniżony lub ośmieszony $(19,4 \%)$, co dziesiąty straszony $(13,6 \%)$ i szantażowany $(11,1 \%)$.

Główne przyczyny agresji to według badanych: wygląd (13,5\%), ubiór $(8,0 \%)$, poglądy $(14,9 \%)$, upodobania $(11,6 \%)$ oraz narodowość $(8,1 \%)$. Rzadziej wskazywane były: zła sytuacja finansowa $(3,8 \%)$, płeć $(4,2 \%)$, kolor skóry $(4,3 \%)$, preferencje seksualne $(4,6 \%)$ i religia $(4,5 \%)^{16}$. Dziewczęta częściej niż chłopcy wskazują, że przyczyny agresji związane są z wizerunkiem, tj. wyglądem oraz ubiorem. Dla chłopców natomiast główne powody agresji słownej mają charakter społeczno-demograficzny - są to na przykład płeć, narodowość, religia, kolor skóry ${ }^{17}$.

Równie istotne dla tego zagadnienia są ustalenia EU Kids Online między innymi w kwestii intencjonalności dzieci i młodzieży w doświadczaniu agresji i przemocy słownej. Celowe poszukiwanie treści zaliczanych do mowy nienawiści podejmuje

16 Tamże, s. 82.

17 Raport Nastolatki 3.0, s. 93. 
niespełna 10\% dzieci w wieku 11-17 lat, a większe zainteresowanie tą aktywnością wykazują starsze grupy wiekowe. Chłopcy nieco częściej szukają w sieci materiałów dotyczących mowy nienawiści niż dziewczęta ${ }^{18}$.

Nastolatki niechętnie informują o doświadczaniu agresji słownej. Tylko co piąty mówi o takim zdarzeniu rodzicowi, opiekunowi $(19,4 \%)$ lub administratorowi sieci (20,8\%), co szósty prosi o pomoc kolegów (17,9\%). Najczęściej jednak nie informują o tym nikogo $(39,0 \%)^{19}$.

Interesująca jest w tym zakresie sugestia autorów raportu Nastolatki 3.0, że może to wskazywać, iż często przyjmują bierną rolę ofiary, ale także w niektórych interakcjach odgrywają podwójną rolę: ofiary i prześladowcy ${ }^{20}$.

Pomimo świadomości istniejących zagrożeń i wręcz osobistego ich doświadczania większość młodych ludzi czuje się w Internecie bezpiecznie; 65\% z nich deklaruje, że jest tak często lub zawsze, 66\% - że często lub zawsze wie, co zrobić, gdy ktoś zachowuje się w sieci w sposób, który im nie odpowiada ${ }^{21}$.

\section{Szkoła wobec mowy nienawiści}

Działalność szkoły na rzecz przeciwdziałania mowie nienawiści rozpatrywać można w dwóch zasadniczych płaszczyznach. Pierwszą stanowią systemowe podstawy edukacji szkolnej, drugą - praktyka edukacyjna. Podstawy edukacji określane są przez: szkolne zestawy programów nauczania, które uwzględniając wymiar wychowawczy, obejmują całą działalność szkoły z punktu widzenia dydaktycznego; programy wychowawcze dotyczące wszystkich treści i działań o charakterze wychowawczym; programy profilaktyki dostosowane do potrzeb rozwojowych uczniów oraz potrzeb danego środowiska. To w nich zawarte są główne założenia systemu edukacyjnego, wśród których powinny się znajdować również te służące zapobieganiu i przeciwdziałaniu mowie nienawiści.

Praktyka edukacyjna traktowana jest jako działania przynoszące konkretne, pozytywne rezultaty, w tym także te dotyczące mowy nienawiści, zawierające w sobie pewien potencjał innowacji, trwałe i powtarzalne, możliwe do zastosowania w podobnych warunkach i w różnych miejscach.

Podstawy systemowe ocenić można przez badanie i analizę tworzących je dokumentów, praktykę - przez analizę wyników badań odnoszących się do tego zagadnienia.

18 Polskie badanie EU Kids Online 2018, s. 125.

19 Co młodzież robi w Sieci? Wyniki badań „Nastolatki 3.0”, https://www.narkomania.org.pl/ czytelnia/internet/co-mlodziez-robi-w-sieci-wyniki-badan-nastolatki-3-0-2/ (dostęp: 22.07.2019).

20 Raport Nastolatki 3.0, s. 92.

21 Polskie badanie EU Kids Online 2018, s. 87. 
Głównymi dokumentami determinującymi system edukacji są podstawy programowe, czyli obowiązkowe na danym etapie edukacyjnym zestawy treści nauczania oraz umiejętności, które muszą być uwzględnione w programach nauczania. Odnosząc przygotowanie szkół do zapobiegania i przeciwdziałania mowie nienawiści w Internecie - o skali i strukturze wynikających z przywoływanych wyżej badań - za przedmiot analizy przyjęto podstawy programowe obowiązujące w latach 2016-2018 22 .

W latach 2016-2017 i częściowo 2018 kształcenie w szkołach podstawowych dzieliło się na dwa etapy edukacyjne: I etap, obejmujący klasy I-III - edukacja wczesnoszkolna, oraz II etap, obejmujący klasy IV-VI ${ }^{23}$.

W podstawie programowej dla tego kształcenia znajdują się dyrektywy odnoszące się do ochrony uczniów przed przemocą i agresją słowną w Internecie. Mają one różne treści, formy i zakresy szczegółowości. Co do treści, to odnoszą się do tego zagadnienia pośrednio lub bezpośrednio; co do formy - to są wyrażane jako cele, zadania, zestawy umiejętności, opisy; w zakresie szczegółowości formułują niektóre zagadnienia wprost albo opisowo i ogólnie kontekstowo.

Już na wstępie kształcenia ogólnego, tworzącego fundament wykształcenia, znajdował się cel, że ma ono budować u uczniów postawy warunkujące sprawne i odpowiedzialne funkcjonowanie we współczesnym świecie, i zadanie przygotowania uczniów do życia w społeczeństwie informacyjnym. Jedną z najważniejszych umiejętności zdobywanych w trakcie kształcenia miała być umiejętność posługiwania się nowoczesnymi technologiami informacyjno-komunikacyjnymi, w tym także dla wyszukiwania i korzystania $\mathrm{z}$ informacji. Trafnie też podnoszono, że środki społecznego przekazu odgrywają coraz większą rolę w życiu zarówno społecznym, jak i indywidualnym, więc każdy nauczyciel powinien poświęcić dużo uwagi edukacji medialnej, czyli wychowaniu uczniów do właściwego odbioru i wykorzystania mediów ${ }^{24}$.

Podstawa dzieliła się na dwa etapy edukacyjne: I etap edukacyjny, obejmujący klasy I-III - edukacja wczesnoszkolna, która była realizowana w formie kształcenia

22 Rozporządzenie Ministra Edukacji Narodowej z dnia 17 czerwca 2016 r. zmieniające rozporządzenie w sprawie podstawy programowej wychowania przedszkolnego oraz kształcenia ogólnego w poszczególnych typach szkół, Dz.U. z dnia 23 czerwca 2016 poz. 895; Rozporządzenie Ministra Edukacji Narodowej z dnia 14 lutego 2017 r. w sprawie podstawy programowej wychowania przedszkolnego oraz podstawy programowej kształcenia ogólnego dla szkoły podstawowej, w tym dla uczniów z niepełnosprawnością intelektualną w stopniu umiarkowanym lub znacznym, kształcenia ogólnego dla branżowej szkoły I stopnia, kształcenia ogólnego dla szkoły specjalnej przysposabiającej do pracy oraz kształcenia ogólnego dla szkoły policealnej, Dz.U. z dnia 24 lutego 2017 poz. 356; Rozporządzenie Ministra Edukacji Narodowej z dnia 30 stycznia 2018 r. w sprawie podstawy programowej kształcenia ogólnego dla liceum ogólnokształcącego, technikum oraz branżowej szkoły II stopnia. Załącznik nr 1. Podstawa programowa kształcenia ogólnego dla czteroletniego liceum ogólnokształcącego i pięcioletniego technikum, Dz.U. z dnia 3 stycznia 2017 poz. 59, 949 i 2203.

23 Był to okres przejściowy wprowadzania zmian w systemie oświatowym wynikający z Ustawy z dnia 14 grudnia 2016 r. Prawo Oświatowe, Dz.U. z dnia 3 stycznia 2017 poz. 59.

24 Rozporządzenie Ministra Edukacji Narodowej z dnia 17 czerwca 2016 r., zał. nr 2, s. 9. 
zintegrowanego; II etap edukacyjny, obejmujący klasy IV-VI, podczas którego były realizowane następujące przedmioty: język polski, język obcy nowożytny, muzyka, plastyka, historia i społeczeństwo, przyroda, matematyka, zajęcia komputerowe, zajęcia techniczne, wychowanie fizyczne, wychowanie do życia w rodzinie, etyka, język mniejszości narodowej lub etnicznej, język regionalny.

W podstawie programowej dotyczącej I etapu edukacyjnego zawarty był cel zadbania o to, aby dziecko odróżniało dobro od zła, a także było świadome przynależności społecznej (do rodziny, grupy rówieśniczej i wspólnoty narodowej). Konkretyzacją tego celu były dwa zadania, a mianowicie dbałość o to, aby dziecko mogło nabywać wiedzę i umiejętności potrzebne do rozumienia świata, w tym zagwarantowanie mu dostępu do różnych źródeł informacji i możliwości korzystania z nich, a także sprzyjanie rozwojowi cech osobowości dziecka koniecznych do aktywnego i etycznego uczestnictwa w życiu społecznym. Realizację celu i zadań umieszczono, jako treści nauczania oraz wymagania szczegółowe, w częściach dotyczących zajęć komputerowych oraz etyki. W pierwszej zadysponowano, że uczeń ma znać zagrożenia wynikające z korzystania z komputera, Internetu i multimediów, a w szczególności mieć świadomość niebezpieczeństw wynikających $\mathrm{z}$ anonimowości kontaktów i podawania swojego adresu, oraz że stosuje się do ograniczeń dotyczących korzystania z komputera, Internetu i multimediów. W drugiej sformułowano postulat przestrzegania przez uczniów reguł obowiązujących w społeczności dziecięcej oraz w świecie dorosłych ${ }^{25}$.

$\mathrm{Na}$ drugim etapie edukacyjnym podstawy programowej też wprowadzały zestaw celów, zadań i wytycznych realizacyjnych, mających wspierać walkę z agresją i przemocą słowną w Internecie. Powiązane były z dwoma konkretnymi przedmiotami, stanowiąc rozwiniętą kontynuację dziedzinową wywodzącą się z obszarów etapu pierwszego. Były to bowiem nadal zajęcia komputerowe i etyka. Jako cel pierwszy zajęć komputerowych wyznaczone zostało bezpieczne posługiwanie się komputerem i jego oprogramowaniem, a także świadomość zagrożeń i ograniczeń związanych z korzystaniem z komputera oraz Internetu. W treściach i wymaganiach szczegółowych powiązanych z tym celem użyto sformułowania, że uczeń przestrzega zasad etycznych i prawnych związanych z korzystaniem z komputera oraz Internetu, ocenia możliwe zagrożenia. W etyce celem podstawowym był zapis o kształtowaniu refleksyjnej postawy wobec człowieka, jego natury, powinności moralnych, a także różnych sytuacji życiowych.

Treści nauczania i wymagania szczegółowe wydają się najbardziej dotyczyć dyspozycji wyrażonej jako uczestnictwo $\mathrm{w}$ grupie, porozumiewanie się $\mathrm{z}$ innymi. $\mathrm{W}$ zalecanych warunkach i sposobach realizacji rekomendowano pełen dostęp do Internetu w trakcie zajęć komputerowych oraz wychowawczy charakter zajęć z etyki, odnoszony do otaczającej uczniów rzeczywistości ${ }^{26}$.

25 Tamże, s. 16-17.

26 Tamże, s. 22-55. 
Ponadpodstawowy poziom kształcenia w okresie objętym badaniem to jeszcze gimnazja, a dalej licea ogólnokształcące, technika, szkoły zawodowe. Dla obrazu przygotowania tego poziomu szkolnictwa do ochrony uczniów przed mową nienawiści w sieci ważne były regulacje zawarte $\mathrm{w}$ podstawach programowych dla liceów i techników (bo to do nich trafiało najwięcej absolwentów gimnazjów). Lektura tego dokumentu wskazuje, że zachowano kierunek zapoczątkowany w odniesieniu do szkoły podstawowej, lokujący to zagadnienie w obszarach dwóch przedmiotów: informatyki i etyki. Na plan pierwszy w informatyce wysuwa się umiejętność korzystania z nowych technologii w sposób twórczy i krytyczny, a jako cele szczegółowe podano: przestrzeganie prawa i zasad bezpieczeństwa, respektowanie prywatności informacji i ochrony danych, praw własności intelektualnej, etykiety w komunikacji i norm współżycia społecznego, oceny zagrożeń związanych z technologią oraz ich uwzględnienie dla bezpieczeństwa swojego i innych. W treściach nauczania i wymaganiach szczegółowych uczniowie mieli bezpiecznie budować swój wizerunek w przestrzeni medialnej oraz respektować obowiązujące prawo i normy etyczne dotyczące korzystania oraz rozpowszechniania oprogramowania komputerowego ${ }^{27}$.

Z kolei w etyce za cele podstawowe przyjęto: kształtowanie rozpoznawania wartości moralnych oraz zdolności odróżniania dobra od zła; dokonywanie trafnej oceny moralnej podejmowanych działań w życiu osobistym, w grupie, szkole, społeczności lokalnej; umiejętność dokonywania etycznej analizy i oceny działań oraz decyzji własnych i innych w świetle wartości moralnych, a także tworzenia hierarchii wartości. W treściach nauczania i wymogach szczegółowych za najistotniejsze przyjmowano zdolność rozpoznawania wartości i powszechne dążenie do dobra ${ }^{28}$.

Przedstawione elementy podstawowych dla systemu edukacji dokumentów programowych wskazują na uwzględnianie w nich niebezpieczeństw wynikających ze zjawiska agresji i przemocy w Internecie. Nie jest to co prawda odrębne traktowanie tej formy komunikowania, w której masowo uczestniczą dzieci w wieku szkolnym, zwłaszcza te uczęszczające do szkół ponadpodstawowych, lecz przygotowywanie do bezpiecznej obecności w całej przestrzeni cyfrowej. Oznacza to, że analizowane zagrożenia były dostrzegane i podejmowane w założeniach programowych, choć odrębną sprawą jest ocena trafności formułowanych celów i zadań czy doboru treści oraz wymogów stawianych uczniom.

Niestety praktyka edukacyjna raczej daleko odbiegała od założeń programowych. Wskazują na to opinie uczniów zawarte w przywoływanych badaniach sondażowych. Prawie $60 \%$ uczniów twierdzi, że nauczyciel nie rozmawiał z nimi

27 https://podstawaprogramowa.pl/Liceum-technikum/Informatyka (dostęp: 10.10.2019).

28 Podstawa programowa kształcenia ogólnego dla gimnazjów i szkół ponadgimnazjalnych, których ukończenie umożliwia uzyskanie świadectwa dojrzałości po zdaniu egzaminu maturalnego (s. 204 i 256-257). Por. Załącznik nr 4 do: Rozporządzenia Ministra Edukacji Narodowej z dnia 23 grudnia 2008 r. w sprawie podstawy programowej wychowania przedszkolnego oraz kształcenia ogólnego w poszczególnych typach szkół (Dz.U. z dnia 15 stycznia $2009 \mathrm{Nr} 4$ poz. 17). 
o tym, co robią w Internecie. Podobny odsetek uczniów nie doświadczył rozmowy z nauczycielem na temat tego, co ich w Internecie zaniepokoiło, a ponad 55\% $\mathrm{z}$ nich nie pamięta, by rozmawiało $\mathrm{z}$ nauczycielem o tym, co powinni zrobić, gdyby w przyszłości coś ich zaniepokoiło. Jedynym regularnie realizowanym działaniem nauczycielskim było podpowiadanie, jak bezpiecznie korzystać z Internetu, ale i tak dotyczyło ono tylko około $40 \%$ uczniów ${ }^{29}$.

Przygotowanie do samodzielnego posługiwania się Internetem przez dzieci i młodzież szkolną dokonuje się w głównie przez samoedukację (68,6\%). Wsparcia dostarczają często starszy brat czy siostra oraz rodzice (21\%). Tylko co dziesiąty badany deklarował, że umiejętności korzystania z Internetu nabył w edukacji szkolnej ${ }^{30}$.

\section{Podsumowanie}

Cyfrowa agresja i przemoc słowna wobec dzieci stały się zjawiskami globalnymi, nasilającym się wraz z intensyfikacją korzystania z Internetu. W szczególny sposób dotyczy to mediów społecznościowych, które dla dzieci są już naturalnym środowiskiem aktywności nie tylko rówieśniczej. Ma to ścisły związek z problemami życia nastolatków i jest pochodną aktów przemocy, konfliktów i mobbingu, obserwowanych w szkole, rodzinie, tradycyjnych mass mediach i środowisku społecznym.

Poczynione wyżej ustalenia pozwalają na sformułowanie odpowiedzi na postawione pytania. Po pierwsze, poziom zagrożenia dzieci i młodzieży szkolnej agresją i przemocą słowną jest znaczący, bowiem co trzeci nastolatek (bez względu na wiek czy płeć) był ofiarą przemocy lub agresji słownej w Internecie. Dominujące formy tych oddziaływań to wyzwiska, poniżanie, ośmieszanie, straszenie, szantażowanie.

Po drugie, polski system edukacyjny (szkoły podstawowe i ponadpodstawowe) nie radził sobie $\mathrm{z}$ tym zagrożeniem i nie nadążał za dynamiką zmian tworzących nowe lub eskalujących istniejące zagrożenia. Dostrzegał je co prawda i włączał do podstaw programowych, ale było to ograniczone do dwóch zaledwie przedmiotów oraz nazbyt ogólne w treściach, celach, zadaniach i formach realizacyjnych.

Badania zjawiska agresji i przemocy słownej wobec dzieci w Internecie mają głęboki sens nie tylko poznawczy, ale też praktyczny. To te przywoływane i wiele innych mogły spowodować, że w kolejnych podstawach programowych nadano temu zagadnieniu znacznie większą rangę oraz sformułowano bardziej konkretne cele i zadania. Pozytywnym przykładem jest zapis, że szkoła ma przygotowywać uczniów do: dokonywania świadomych i odpowiedzialnych wyborów w trakcie korzystania z zasobów dostępnych w Internecie, krytycznej analizy informacji, bezpiecznego

29 EU Kids, s. 48, 49.

30 Raport z badania Nastolatki 3.0, s. 15. 
poruszania się w przestrzeni cyfrowej, w tym nawiązywania i utrzymywania opartych na wzajemnym szacunku relacji z innymi użytkownikami sieci ${ }^{31}$.

Nadal jednak potrzebne są kolejne badania i wynikające $z$ nich rekomendacje edukacyjne. Trafnie to wyrazili Jacek Pyżalski, Aldona Zdrodowska, Łukasz Tomczyk i Katarzyna Abramczuk, autorzy raportu z badań EU Kids, stwierdzając, że „(...) szkoła potrzebuje koncepcji i wsparcia w zakresie »oswajania « Internetu zarówno w sferze dydaktyki, jak i wychowania” i że „(...) ze względu na bogactwo problemów i rolę Internetu w życiu młodych ludzi nie rozwiążą tych wszystkich kwestii zajęcia komputerowe/informatyczne" 32 .

\section{Bibliografia}

Materska K., Taraszkiewicz B. (red.), Ekologia informacji a zasoby informacyjne w bibliotekach i cyberprzestrzeni, Biblioteka Uczelniana Akademii Pomorskiej, Pedagogiczna Biblioteka Wojewódzka w Słupsku, Stowarzyszenie Bibliotekarzy Polskich - Zarząd Oddziału, Słupsk 2017.

Kreft J. (red.), Facebook. Oblicza i dylematy, Wydawnictwo Uniwersytetu Jagiellońskiego, Kraków 2017.

Gogołek W., Komunikacja sieciowa. Uwarunkowania, kategorie i paradoksy, Oficyna Wydawnicza ASPRA-JR, Warszawa 2010.

Jenkins H., Ford S., Green J., Rozprzestrzenialne media. Jak powstają wartości i znaczenia w sieciowej kulturze, Wydawnictwo Uniwersytetu Łódzkiego, Łódź 2018.

„Lubelski Rocznik Pedagogiczny” 2017, t. XXXVI.

Maciąg R., Pragmatyka Internetu: Web 2.0 jako środowisko, Wydawnictwo Uniwersytetu Jagiellońskiego, Kraków 2013.

Milerski B., Śliwerski B., Pedagogika, Wydawnictwo Naukowe PWN, Warszawa 2000.

Muchacki M., Cywilizacja informatyczna i Internet, Oficyna Wydawnicza Impuls, Warszawa 2014.

Ogonowska A., Współczesna edukacja medialna: teoria i rzeczywistość, Wydawnictwo Naukowe Uniwersytetu Pedagogicznego, Kraków 2013.

Ptaszek G., Edukacja medialna 3.0. Krytyczne rozumienie mediów cyfrowych $w$ dobie Big Data $i$ algorytmizacji, Wydawnictwo Uniwersytetu Jagiellońskiego, Kraków 2019.

Rozporządzenia Ministra Edukacji Narodowej z dnia 23 grudnia 2008 r., Dz.U. z dnia 15 stycznia $2009 \mathrm{Nr} 4$ poz. 17.

Rozporządzenie Ministra Edukacji Narodowej z dnia 17 czerwca 2016 r., Dz.U. z dnia 23 czerwca 2016, zał. nr 2.

Rozporządzenie Ministra Edukacji Narodowej z dnia 14 lutego 2017 r., Dz.U. z dnia 24 lutego 2017 poz. 356.

Rozporządzenie Ministra Edukacji Narodowej z dnia 30 stycznia 2018 r., Dz.U. z dnia 2 marca 2018 poz. 467 , zał. nr 1 .

31 Rozporządzenie Ministra Edukacji Narodowej z dnia 30 stycznia 2018 r. w sprawie podstawy programowej kształcenia ogólnego dla liceum ogólnokształcącego, technikum oraz branżowej szkoły II stopnia, DZ.U. z dnia 2 marca 2018 poz. 467, s. 5.

32 EU Kids, s. 157-158. 
Podstawa programowa kształcenia ogólnego dla czteroletniego liceum ogólnokształcącego i pięcioletniego technikum, Dz.U. z dnia 3 stycznia 2017 poz. 59, 949 i 2203.

Spitzer M., Cyberchoroby. Jak cyfrowe życie rujnuje nasze zdrowie, Wydawnictwo Dobra Literatura, Słupsk 2016.

Zimbardo Z.G., Ruch F.L., Psychologia i życie, Wydawnictwo Naukowe PWN, Warszawa 1996.

\section{Źródła internetowe}

Cichla J., Dynamika i uwarunkowania przemian psychospołecznego funkcjonowania kobiet ofiar przemocy domowej - w trakcie procesu terapeutycznego, https://www.sbc.org.pl/dlibra/publication/104443/edition/98297/content (dostęp: 3.08.2019).

EU Kids Online 2018, https://www.academia.edu/38511454/Pyżalski_J._Zdrodowska_A._Tomczyk_Ł._Abramczuk_K._2019_._Polskie_badanie_EU_Kids_Online (dostęp: 15.10.2019).

Małagocka K., Nowowiejski M., 80 proc. dzieci w wieku 7-8 lat ma własny smartfon. Korzystaja $z$ niego średnio 2,5 godziny dziennie, 2017, https://biznes.newseria.pl/news/80-proc-dzieci-w-wieku,p1003907867 (dostęp: 15.03.2019).

Nastolatki 3.0 Wybrane wyniki ogólnopolskiego badania uczniów w szkole, https://akademia. nask.pl/badania/RAPORT\%20-\%20Nastolatki\%203.0\%20-\%20wybrane\%20wyniki\%20 bada\%C5\%84\%20og\%C3\%B3lnopolskich.pdf (dostęp: 15.10.2019).

Podstawa programowa do przedmiotu informatyka, https://podstawaprogramowa.pl/Liceum-technikum/Informatyka (dostęp: 10.10.2019).

Prensky M., Digital Natives, Digital Immigrants, http://desarrollodocente.uc.cl/images/Innovaci\%C3\%B3n/Juegos/Digital_Natives_Digital_Inmigrants.pdf (dostęp: 20.03.2019). 